\title{
A Magical Key to Female Sexual Dysfunction, Sexual Counseling
}

\author{
Kadın Cinsel Disfonksiyonunda Sihirli Bir Anahtar: Cinsel Danıșmanlık
}

\begin{abstract}
\begin{tabular}{|c|}
17 \\
17 \\
\end{tabular}
\section{ABSTRACT}

This study aimed to express the steps, importance, and benefits of sexual counseling given to women with sexual problems. Sexuality is a complicated process that is shaped by the interaction of many emotional, mental, and behavioral elements. Having a sexual relationship and being able to do it without any problems is an important aspect that affects women's quality of life. Studies on sexuality have improved rapidly within the last 20 years. However, due to such factors as condemnation, shyness, unawareness, misbeliefs, or limited opportunities, women with sexual problems may still fail to find solutions to their problems. Sexual counseling is the assistance provided to clients and couples to eliminate a lack of knowledge, correct wrong information and beliefs, and informing them about sexual myths. Sexual counseling helps women to overcome the problems that they perceive unsolvable and to live sexuality freely.
\end{abstract}

Keywords: Sexual dysfunction, sexual function, sexuality, sexual counseling

\section{öZ}

Cinsellik, duygu, düşünce ve davranışsal pek çok unsurun karşılıklı etkileșimi ile şekillenen karmaşık bir süreçtir. Cinsel ilişki yaşayabilmek ve bunu herhangi bir sorun yaşamadan yapabilmek kadınların yaşam kalitesini etkileyen önemli bir boyuttur. Cinsellikle ilgili çalıșmalar son 20 yılda hızlı bir gelişme kaydetmiştir. Fakat buna karşın kadınlarda ayıplanma, utanma, farkında olmamak, yanlıs inançlar ya da imkanların sınırlı olması nedeniyle cinsel problem yaşayan kadınlar bu sorunlarına bir çözüm bulamayabilirler. Cinsel danışmanlık cinsellikle ilgili bilgi eksikliğinin giderilmesi, yanlış bilgilerin ve inançların düzeltilmesi, cinsel mitler hakkında bilgilendirme amacıyla danışanlara veya çiftlere yardımcı olmaktır. Cinsel danışmanlık, kadının çözümsüz gördüğü cinsel problemlerini așmasına ve cinselliğini özgürce yaşamasına destek olur.

Anahtar Kelimeler: Cinsel disfonksiyon, cinsel fonksiyon, cinsellik, cinsel danıșmanlık

\section{Introduction}

Sexuality is the social behavior of individuals or couples. Religious or social effects change an individual's response to sexuality. Masters and Johnson connect sexual response to two fundamental physiological changes: the increase in the blood flow of some parts of the body and the increase in muscle tension. Besides, an analysis of female orgasm indicates three key points called physiological, psychological, and sociological. In this regard, according to Masters and Johnson, fear of performance or social pressures reveal themselves as failure to reach orgasm for women and erection problems for men $(1,2)$.

Sexuality is a multidimensional concept that requires physical and emotional participation. Sexuality and sexual intercourse should not be limited only with the genital system. The genital system forms the majority of sexuality, but as it does not approach the human body as a whole, it is limited only with reproduction. Focusing only on the genital area during sexual intercourse puts skin -the largest erogenous area in the human body- into second place. In this regard, clients and their partners should be encouraged to identify the erogenous areas in their body (3). On the other hand, factors that have effects on sexual health include physiological and emotional health, alcohol and substance use, familial relations, sexual abuse experienced in the past, and other traumatic events (4).

This study addresses the importance of sexual counseling for women and counseling for sexual dysfunctions.

\section{Sexual Counselor}

In order to give sexual counseling, one needs to receive comprehensive training, mainly on personal and couple therapies. Such a training process should also include a kind of internship (5). 
A sexual counselor should have a holistic view while evaluating the client, and $\mathrm{s} /$ he should not ignore some moral and legal issues. Boundaries of the therapy should also be identified well (6).

Issues such as honesty, privacy, and confidentiality should be prioritized. Information provided by the client should be welcomed attentively, and the sessions should be conducted in a professional framework. Couples may sometimes be given assignments (7).

\section{Sexual Dysfunctions and Counseling}

\section{Sexual Desire Disorders}

Diagnostic and Statistical Manual of Mental Disorders - fifth edition (DSM-V) defines sexual desire disorder as "persistently or recurrently deficient (or absent) sexual fantasies and desire for sexual activity that causes marked distress or interpersonal difficulty". Diagnosis requires a "recurrent and persistent" complaint. The current prevalence of sexual dysfunction in women is reported to be between $30 \%$ and $60 \%$. The most prevalent female sexual dysfunction in women is "sexual desire and arousal disorder" (8).

A decrease in sexual desire and sexual activity could cause problems between couples. Significant differences in sexual desire between couples might cause disappointment and tension between the couples (9). People who have sexual desire disorder are far from having sexual fantasies and satisfying themselves sexually (10).

Assessment of people who experience a decrease in sexual desire should include several factors such as the couples' age, hormone features, physical health, and frequency of sexual activity. The person's psychological strength, limitations, values, and attitudes should be identified. Besides these, one of the factors that affect sexual desire is anxiety. Anxiety could prevent pleasure. Another critical factor that affects sexuality is the interaction between couples, which is negatively affected by such factors as anger, lack of communication, and power conflicts. Each spouse's family features, religious beliefs, cultural differences, attitudes, and values contribute to the sexual life of couples. To solve these kinds of problems, the individual should be approached holistically, and trained about sexual intimacy. The counselor should consider various reasons and be flexible in the treatment of sexual desire disorder (11).

Clinical assessment: The evaluation of the person with a sexual desire disorder should include the formation of hypotheses about the reasons for the problem. First impressions, personal responses, relationships, and collective lives should be investigated. In the early period of the treatment, aims and couples' expectations should be identified. Besides, the client should be asked questions for the evaluation of her sexual relationship (3). Sessions at the clinical assessment phase involve the questioning of sexual fantasies and thoughts, sexual activity and its frequency, and the situations disturbing the client. These kinds of sessions also involve privacy issues and the client's viewpoint about her relationship. Starting from the beginning of the treatment, the client should be observed in terms of her negative thoughts about self, spouse, and family. This assessment helps to identify the direction of the therapy. Besides, the use of new psychometric tools for the clinical assessment of counselors has been approved. Female sexual dysfunction can be assessed using valid and reliable sexual function scales such as the Female Sexual Function Index (FSFI) $(9,12)$.

Positive treatment results for people who have sexual desire problem could be maintained under some appropriate conditions, which include the followings:

- Couples' having common sexual desire,

- Couples' having no psychiatric problem,

- The client's willingness to sharing her negative past experiences,

- Identification of the factors that cause stress and anxiety,

- Elimination of the negative thoughts about sexual desire,

- Ability to discuss with the spouse about the treatable difficulties in their relationship,

- Sharing negative religious beliefs (11).

Reasons such as anxiety, depression, and bad body image prevent the treatment of sexual desire disorder. Lack of sexual desire is a complicated issue for the individual. Pessimism is a reaction in case of failure. The counselor should support his/her client in order to solve the problem. Besides, by asking more questions, the counselor should manage the process in terms of the way s/he contributes to the solution for lack of sexual desire. Throughout the treatment process, clients learn about sexual satisfaction slowly. These people should learn to have control over their feelings, behaviors, and sexual satisfaction (10).

Clinical approach: Treatment of sexual desire disorder should primarily include individual and relational issues. The treatment aims to bring sexual desire back. The success of the treatment in these kinds of patients is to maintain satisfaction in the relationship. In some cases, people create personal expectations for themselves. Disappointments might happen when these expectations are not met. The woman might think that she is not valued enough, which could cause a lack of sexual desire. The counselor should be able to reveal these expectations accurately (3).

An overall analysis of the clients who have sexual problems indicates that what couples wonder and worry about is whether their spouse desires them. Pleasure and desire decrease as anxiety increases. The main purpose of the treatment for lack of sexual desire is to eliminate this anxiety. The counselor should start the therapy by explaining the aim and the problems. Another therapy method could be objecting to the ideas that maintain anxiety. For this, the definition of sexuality and sex should be expanded, and focusing solely on sexual intercourse should be prevented (13).

Another case that should be focused on the therapy process is the emotional process that develops during the therapy. The counselor asks couples to explain their feelings to each other so that emotional barriers can be eliminated. The counselor should support the couples' erotic thoughts and fantasies, using which s/he should make perceptions positive (11).

Another side of the therapy is the discussion about the client's sexual desires, needs, and preferences. Some misbeliefs may not be eliminated 
without talking with the counselors. Systemic assignments could be given regarding sexual intimacy and fantasies. Individual assignments could include physical exercises, fantasizing, guided masturbation, review of visual materials, or regular use of sex materials. Assignments for couples may include discussing sexual and emotional needs and exercises for the solution to the problems (10).

\section{Sexual Arousal Disorders}

DSM-V defines sexual arousal disorder as a lack or absence of desire for sexual activity or fantasies, or lack or absence of sexual excitement/ pleasure during sexual intercourse (14). American Urological Association divides sexual arousal disorders as primary, secondary, and situationspecific. Through a detailed history taken from the client, the counselor should identify whether this problem is related to the sexual desire problem, or the decrease in sexual desire developed secondarily. Sexual arousal is a complicated issue to assess. There are limited findings of normal arousal, which is dependent on living conditions, age, and sexual experiences. The physiological response that an individual gives to sexual stimulation is not always at the same level (3).

Changes in the genital area happen with the increase in the bloodstream in the vaginal and clitoral area. A bloodstream increase in the middle wall of the vagina leads to lubrication. A bloodstream increase in the clitoral area leads to fullness and sensory changes (15).

Sexual arousal has both psychological and physical aspects. Some psychological aspects include sexual expectation, anticipatory sexual behaviors, psychic arousal, and sensory extension. Physical aspects of sexual arousal include swelling in vagina entrance, wetness, lubrication, and tingling sensation. The identification of each aspect separately is essential for the treatment of sexual arousal disorder (16).

Sexual problems such as sexual arousal disorder deteriorate women's quality of life and affect their relationships with their partners. While there are cardiovascular, neurologic, and psychological cases accompanied by this case, cancer, and its treatment could also cause sexual arousal disorder. Besides, surgical menopause, which causes a decrease in estrogen hormone, also affects sexual arousal. In addition to these medical cases, cognitive, emotional, and psychodynamic factors cause changes in sexual functions, too (3).

Clinical assessment: Assessment of the person with sexual arousal should be done thoroughly, and the counselor should keep in mind that the information provided by the client might be insufficient (16).

In the first assessment, with an interview session that takes about 45 to 60 minutes, a complete psychosocial, medical, and psychosexual history are taken. Finding out what causes stress in women with sexual arousal disorder has excellent contributions to the treatment. Besides, external genital organs should be examined. Some methods used for genital stimulations include photoplethysmography for the evaluation of the genital stimulus, measurement of labial temperature, Gold Sheffield electrode, and Doppler ultrasonography of clitoral blood flow (17).

Clinical approach: Approach to women's sexual arousal problem includes five rules:
1. The woman's and her partner's views on sexual intercourse are essential because each has a different point of view.

2. The woman's psychology and psychopathology, which includes her ideas, values, or general notions, should be evaluated.

3. The woman and her partner should be evaluated as a whole in terms of the relationship.

4. The couple's family and social life should be observed.

5. The effects of social, cultural, and historical factors should be identified in the evaluation phase (16).

\section{Orgasmic Disorders}

DSM-V defines orgasmic disorders as delays in almost every sexual activity, a significant delay in orgasm, lack of orgasm, or low-intensity orgasm. Orgasmic disorder in sexual life could be lifelong or acquired, general or psychological, and caused by situational or both psychological and medical reasons. This dysfunction causes deterioration in interpersonal relationships and stress. The orgasmic disorder might have been caused by misinformation about sex, a decrease in sexual desire, perception of sexual identification, or the effects of medical treatments. Stress, tiredness, general health state, and other personal features also affect sexual desire and response in a negative way (14).

Evaluation of orgasmic disorder in women should include a detailed psychological, social, relational, and medical anamnesis. Besides, the counselor needs to understand the source of the sexual dysfunction. The woman's orgasm problem should be investigated in terms of its frequency, whether it is primary or secondary, and how long it has been experienced. Besides, some other changes that she is going through should be taken into consideration, and the woman's or couple's expectations from the treatment should be investigated (18).

Clinical assessment: It is not known which approach is the most successful one in the treatment of the female orgasmic disorder. Another problem that affects the success of a sexual counselor is the duration of the dysfunction. If dysfunction has been experienced for a long time, and if the woman is applying it as a norm in her life, it could be hard to make her get used to a new change (19).

Clinical approach: Instruction of effective sexual arousal techniques could be helpful for the female orgasmic disorder. Guided masturbation is also an effective method. The counseling process includes instructions for women about how to reach orgasm, about ways of reaching orgasm, and about revealing her body. The woman is guided about understanding what stimulates her, which practices give pleasure to her, or which practice is hard or unpleasant during sexual intercourse. In the first phases of the exercises, the woman is suggested to use a mirror to know her genital organs. She is recommended to have sexual fantasies in order to increase her sexual response, feel her senses, and change her negative thoughts about masturbation. Some women ignore their sexuality and feel guilty during their sexual relationships. Therefore, fantasies should aim to improve the woman's perspective of self as a sexual individual. These fantasies should include both emotional and physical aspects of sex, and sexual function should involve the participation of both aspects. After these exercises are completed, the 
next step is to guide the client to sexual intercourse. Supplementary stimulators might be needed at this stage. Coital intercourse during sexual intercourse is important as it increases orgasm frequency by enhancing clitoris contact $(19,20)$.

\section{Dyspareunia}

DSM-V defines dyspareunia as permanent or recurrent pain during sexual intercourse, which is not related to vaginismus or a decrease in lubrication. Pain during sexual intercourse harms sexual life. Secondary sexual disorders could also accompany the pain. This case causes negative changes in female sexual behaviors, harmful behaviors, deterioration in partner relationships, a decrease in self-confidence, and mood disorders. Women with Dyspareunia state that they have severe pain during coitus. Besides, they also have pain in penetration cases such as during vaginal tampon or gynecologic examination. Although pain during sexual intercourse is thought to develop mostly during menopause due to a decrease in vaginal elasticity, it is reported to be prevalent mostly between the ages of 18 and $24(21,22)$.

Clinic assessment: Several factors may cause physical pain during sexual intercourse. Pain may be caused by congenital anomalies of the genital system, urinary system infections, and acute or chronic diseases. A decrease in estrogen values following physical menopause or surgical menopause -due to its effects on the vagina- could cause pain during sexual intercourse. Episiotomy or other gynecological surgical procedures could cause painful sexual intercourse. Besides, woman's negative thoughts, sexual taboos, stress or anxiety, and lack of sexual education also, despite not causing pain alone, are among factors that increase pain $(23,24)$. Assessment should be done in terms of the exact location of pain during sexual intercourse, severity and type of pain, whether the pain develops before or after penetration, how long the pain lasts, whether it is continuous or occasional, whether there is pain without sexual stimulus, and the time when the pain is felt during sexual intercourse. The effects of pain on the couple's sexual life should also be identified. With this purpose, patients could be administered scales such as FSFI that assesses sexual life $(25,26)$.

Clinical approach: The most important phase of therapy in painful sexual intercourse is training. Patients generally think that the problem will be solved at the beginning of the counseling. However, the related literature indicates that it is quite hard to eliminate the pain. Instead, the client should be asked to tell about her expectations. The purpose of counseling is to help couples to maintain a satisfying sex life again. The counselor should know the source of the problem well. As facing the pain will scare the client, she might avoid mentioning her real problem. Besides, it is important to tell women who experience pain during sexual intercourse that their pain is real. The client should be asked to keep a diary that indicates under which conditions the pain is the lowest and under which ones it is the highest (26). The client could be taught relaxation techniques and exercises. Women who experience pain during sexual intercourse usually avoid observing their genital areas. It is important to help them accept their genital organs again. They could be taught Kegel exercises. The client should be told that the ultimate purpose is not to increase the frequency of sexual intercourse but to increase sexual desire, stimulus, and satisfaction. This situation decreases anxiety and helps to focus on the interviews to be conducted. Besides, in order to maintain recovery in sexual life, the woman should find herself attractive. The counselor should make the client have the self-belief that she is cognitively and behaviorally attractive. The client could be recommended to read an erotic book or watch a video before sexual intercourse or when she is alone at home. She should be told that as masturbation increases sexual desire and stimulation, she should masturbate. The client should be informed about the importance of sexual stimulation before penetration. Many couples focus on sexual intercourse. The client should be explained that sex involves many cases that involve satisfaction and orgasm. Pain during sexual intercourse may cause couples to be deprived of many experiences $(23,27)$.

\section{Conclusion}

The purpose of sexual counseling is to help clients or couples to cover a lack of knowledge about sexuality, to correct wrong information and beliefs, and to learn about sexual myths. The aim in sexual counseling is to decrease the woman's sexual fears and worries, increase her emotional and sexual response, decrease her anger at her husband, help her experience new emotional and sexual techniques, increase communication between couples, eliminate thoughts that distract attention during sexual intercourse, and decrease her prejudices about having orgasm. Therefore, sexual counseling is a magical key that could be used in solving women's sexual problems, setting their sexual life free, and increasing their quality of life.

\section{Ethics}

Peer-review: Externally peer-reviewed.

Author Contributions: Concept - Ç.B., E.A.; Design - C..B., E.A.; Supervision - Ç.B., E.A.; Literature Search - Ç.B., E.A.; Writing Manuscript - Ç.B., E.A.; Critical Review - E.A.

Conflict of Interest: No conflict of interest was declared by the authors.

Financial Disclosure: The authors declared that this study received no financial support.

\section{References}

1. Bradford A, Meston CM. Senior sexual health: The effects of aging on sexuality. In: Vandeccreek FL, Bley JW, editors. Innovations in Clinical Practice: Focus on Sexual Health. Sarosta, FL: Professional Resource Press; 2007. p. 35-46.

2. Küçük N, Kaydırak MM, Bilge Ç, Şahin NH. Evaluation of the effect of obesity on self-respect and sexuality in women. Anatolian Journal of Psychiatry 2018; 19: 126-34.

3. Basson R. Sexual Desire/arousal disorders in women. In: Leiblum SR, editor Principles and practice of sex therapy. New York, Guilford; 2007. p. 25-53.

4. Clayton $\mathrm{AH}$, Valladares Juarez EM. Female sexual dysfunction. Psychiatr Clin North Am 2017; 40: 267-84.

5. Zamani M, Tavoli A, Yazd Khasti B, Sedighimornani N, Zafar M. Sexual therapy for women with multiple sclerosis and its impact on quality of life. Iran J Psychiatry 2017; 12: 58-65.

6. Ridley J. What every sex therapist needs to know. In: Hertlein KM, Weeks GR, Gambescia N, editors. Systemic sex therapy. New York, Routledge; 2015. p. 3-12. 
7. Parsa P, Tabesh RA, Soltani F, Karami M. Effect of group counseling on quality of life among postmenopausal women in Hamadan, Iran. J Menopausal Med 2017; 23: 49-55.

8. Mullard A. FDA approves female sexual dysfunction drug. Nat Rev Drug Discov 2015; 14: 669.

9. Malary M, Pourasghar M, Khani S, Moosazadeh M, Hamzehgardeshi Z. Psychometric properties of the sexual interest and desire inventory-female for diagnosis of hypoactive sexual desire disorder: The Persian Version. Iran J Psychiatry 2016; 11: 262-8.

10. Weeks GR, Hertlein KM, Gambescia N. Hypoactive sexual desire disorder treatment. In: Hertlein KM, Weeks GR, Gambescia N, editors. Systemic sex therapy. New York, Routledge; 2015. p. 52-85.

11. Gambescia N, Weeks G. Sexual dysfunction. Kluwer Academic Publishers: Norwell, MA; 2006. p. 351-68.

12. Bilge C, Aslan E. Sexual counseling in gynecological cancers: A case report. Turk J Oncol 2018; 33: 33-7.

13. Pyke R, Clayton A. What sexual behaviors relate to decreased sexual desire in women? A review and proposal for end points in treatment trials for hypoactive sexual desire disorder. Sex Med 2017; 5: 73-83.

14. Nappi RE, Cucinella L, Martella S, Rossi M, Tiranini L, Martini E. Female sexual dysfunction (FSD): Prevalence and impact on quality of life (QoL). Maturitas 2016; 94: 87-91.

15. Brotto LA. Evidence-based treatments for low sexual desire in women. Front Neuroendocrinol 2017; 45: 11-7.

16. Wylie KR, Jones RH. Inhibited arousal in women. In: Hertlein KM, Weeks GR, Gambescia N, editors. Systemic sex therapy. New York, Routledge; 2015. p. 152-68.

17. Faubion SS, Parish SJ. Sexual dysfunction in women: Can we talk about it? Cleve Clin J Med 2017; 84: 367-76.
18. Kope SA. Female sexual arousal and orgasm: Pleasures and Problems. In VanderCreek L, Peterson F, Bley J, editors. Innovations in Clinical Practices: Focus on Sexual Health. Sarasota, Professional Resource Press; 2007. p. 93106

19. McCabe M. Female orgasmic disorder. In: Hertlein KM, Weeks GR, Gambescia N, editors. Systemic sex therapy. New York, Routledge; 2015. p. 171-86.

20. Heiman JR. Orgasmic disorders in women. In: Leiblum SR, editor. Principles and practice of sex therapy. New York, Guilford; 2007. p. 84-123.

21. Binik YM, Bergeron S, Khalife S. Dyspareunia and vaginismus: So-called sexual pain. In: Leiblum SR, editor. Principles and practice of sex therapy. New York, Guilford: 2007. p. 124-56.

22. Mitchell KR, Geary R, Graham CA, Datta J, Wellings K, Sonnenberg P. et al. Painful sex (dyspareunia) in women: prevalence and associated factors in a British population probability survey. BJOG 2017; 124: 1689-97.

23. Simonelli C, Eleuteri S, Petruccelli F, Rossi R. Female sexual pain disorders: dyspareunia and vaginismus. Curr Opin Psychiatry 2014; 27: 406-12.

24. Graziottin A, Gambini D, Bertolasi L. Genital and sexual pain in women. Handb Clin Neurol 2015; 130: 395-412.

25. Rosenbaum TY. Physical therapy management and treatment of sexual pain disorders. In: Leiblum SR, editor. Principles and Practice of Sex Therapy. New York, Guildfor Press; 2007. p. 157-77.

26. Meana M, Binik YM, Thaler L. Assesment of sexual dysfunction. In: Hunsley J Mash EJ, editors. A guide to assesments that work. New York, Oxford University Press; 2008. p. 464-87.

27. Meana M. Painful Intercourse: Genito-pelvic Pain/penetration disorder. In Hertlein KM, Weeks GR, Gambescia N, editors. Systemic sex therapy. New York, Routledge; 2015. p. 191-206. 